\title{
Вятский священник и педагог-методист Н. Н.Блинов
}

\author{
Владимир Помелов \\ университет ФГБОУ ВО «Вятский государственный университет», кафедра педагогики, Россия \\ ORCID 0000-0002-3813-7745 \\ vladimirpomelov@mail.ru \\ Людмила Сахарова \\ ФГБОУ ВО Кировский ГМУ Минздрава РФ, кафедра гуманитарных и социальных наук, Россия \\ ORCID 0000-0002-6445-6416 \\ slg75@rambler.ru
}

\section{Василий Сахаров}

ФГБОУ ВО «Вятский государственный университет», кафедра педагогики, Россия ORCID 0000-0002-0155-6188

vas701@rambler.ru

V. Pomelov, L. Sakharova, V. Sakharov, Vyatka priest and teacher-methodologist N. N. Blinov, Elpis, 23 2021: 77-87.

V. Pomelov, L. Sakharova, V. Sakharov, Wiacki ksiadz i nauczyciel-metodolog N. N. Blinov, Elpis, 23 2021: 77-87.

\begin{abstract}
The article reveals the pedagogical and methodological activities of the famous Vyatka priest and teacher-methodologist N.N. Blinov, who clearly showed himself to be a priest, a practical teacher, a methodologist of primary education, a local historian and a researcher of the history of the Udmurt people. The theoretical and practical work of N. N. Blinov is a bright page in the history of the Vyatka region.
\end{abstract}

Streszczenie: Artykuł ukazuje działalność pedagogiczną i metodologiczną słynnego księdza Wiackiego i nauczyciela-metodologa N.N. Blinova, który dał się poznać jako ksiądz, praktyczny nauczyciel, metodolog edukacji podstawowej, lokalny historyk, badacz historii ludu Udmurtów. Teoretyczne i praktyczne opracowania N. N. Blinova tworzą jasną kartę historii regionu Wiackiego.

\begin{abstract}
Аннотация: В статье раскрывается педагогическая и методическая деятельность известного вятского священника и педагога -методиста Н. Н. Блинова, ярко проявившего себя как священник, практический учитель, методист начального обучения, краевед и исследователь истории удмуртского народа. Теоретическая и практическая работа Н. Н. Блинова представляет собой яркую страницу в истории Вятского края.
\end{abstract}

Keywords: Vyatka governorate, N. N. Blinov, K. D. Ushinsky, The bee, The education is the light

Słowa kluczowe: Gubernia Wiacka, N. N. Blinov, K. D. Ushinsky, „Pszczółka”, „Nauczanie jest światłem”

Ключевые слова: Вятская губерния, Н. Н. Блинов, К. Д. Ушинский, «Пчелка», «Ученье - свет»

\section{(i) (2)}

В России, также, впрочем, как и в других европейских странах, на начальных этапах развития образования исключительно важную роль в распространении просвещения играли христианские проповедники. Именно они были первыми учителями своего народа. В своей повседневной деятельности они, как правило, гармонично сочетали священническую и педагогическую работу.

В данном материале характеризуется личность одного из известных российских священников и педагогов-методистов второй половины XIX - начала XX вв. Николая Николаевича Блинова.

При этом в большей степени освещается его просветительская и методическая работа. Период деятельности Н. Н. Блинова совпал со временем активизации развития образования в России в пореформенный период.

Всё большее внимание в прогрессивных педагогических кругах стало уделяться развитию образования в отдаленных от столицы регионах, а одной из региональных особенностей развития образования в российской провинции во второй половине XIX - начале XX вв. стало появление значительного количества педагогов-методистов, деятельность которых осуществлялась не только в Санкт-Петербурге, Москве и других крупных городах, но также и вдали от значительных образовательных и культурных центров.

Проявление этой особенности стало важным следствием развернувшегося с 1860-х гг. демократического движения передовой интеллигенции, стремившейся к 
всемерному распространению просвещения посредством «хождения в народ», открытия школ, написания и издания большими для того времени тиражами, доступной по цене и содержанию «народной» литературы, прежде всего букварей и других учебно-методических пособий для начальной школы.

Авторы многих из этих работ, такие как А. Баранов, В. Руднев, Н. Щербина, А. Филонов, А. Радонежский, М. Фенелонов, Н. Ермин, Н. Некрасов и др., выступали подчас эпигонами К. Д. Ушинского, В. И. Водовозова, Н. А. Корфа, В. Я. Стоюнина, широко и далеко не всегда достаточно вдумчиво использовавшими новаторские идеи выдающихся русских педагогов, и при этом не только не развивавшими эти идеи вглубь, но нередко искажавшими и утрировавшими то ценное, что содержалось в трудах классиков российской педагогики.

Передовые педагоги второй половины XIX в., такие как К. Д. Ушинский, Д. Д. Семенов, Н. В. Шелгунов и др., подвергали острой критике охарактеризованных выше авторов (Ušinskij, 1989e, s. 474-496; Semenov, 1953, s. 165-220).

Одним из главных пороков подобной методической квазилитературы было стремление авторов к «оригинальности», «ниспровержению авторитетов» в ущерб качеству дидактического материала. В одной из рецензий справедливо отмечалось, что «авторы неудержимо распложающихся учебников и учебничков смотрят чрезмерно светло и преувеличенно на «особенности» своих произведений» (А.N., 1893, s. 290). Так, И. Сильченко, автор «Родной азбуки» (Одесса, 1893) вводил в своем пособии буквы «ъ» и «ь» в числе самых первых и, тем самым, «опровергал» мнение К. Д. Ушинского, как раз советовавшего в «Руководстве в преподавании по «Родному Слову» «избегать слишком ранней встречи» с этими буквами.

В то же время, отечественные ученые разных поколений (Н. Ф. Бунаков, Н. В. Чехов, Н. И. Ашмарин, Н. А. Константинов, В. Я. Струминский, В. Б. Помелов и др.) в своих трудах давали высокую оценку некоторым работам провинциальных авторов, среди которых были уроженцы и Вятской губернии (Pomelov, 1988).

В число немногих оригинальных, творческих работ для начальной школы Н. А. Константинов и В. Я. Струминский, включали наряду с «Азбукой» Л. Н. Толстого и «Наглядной азбукой» Ф. Ф. Павленкова, пособия вятского сельского священника и учителя $\mathrm{H}$. Н. Блинова «Ученье - свет» и «Пчелка»; относили их автора к плеяде «замечательных, талантливых и самоотверженных одиночек-педагогов» (Konstantinov \& Struminskij, 1953, s. 172).

Аналогичные высказывания в адрес Блинова содержатся в трудах выдающихся русских педагогов Н. Ф. Бунакова (9, s. $337 ; 10$, s. 97) и Н. В. Чехова (Čehov, 1912, s. 57).

Н. Ф. Бунаков стал автором статьи о Н. Н. Блинове в многотомном «Критико-биографическом словаре русских писателей и ученых» (Bunakov, 1892, s. 381-389).
Выдающийся российский гуманист, писатель В. Г. Короленко также положительно оценивал подвижническую писательскую и педагогическую деятельность Н. Н. Блинова, высоко ценил его методические работы и считал, что вятский педагог заслужил «высокое почетное имя» (Izerginan, 1990, s. 76).

Значительный интерес к творческому, и в частности методическому, наследию Н. Н. Блинова проявляют и современные исследователи (Gorbunov, 1981). Несомненно, Н. Н. Блинов был самым видным учителем, методистом и земским деятелем на Вятской земле; кроме того, Блинов был известной и популярной личностью в российских педагогических кругах.

В настоящее время региональная печать знакомит читателя с некоторыми ранее не публиковавшимися по идеологическим соображениям работами Блинова, которые выходят сейчас с соответствующими комментариями специалистов (Blinov, 1991, Gorbunov, 1991).

В то же время, методическое наследство Н. Н. Блинова во многом остается невостребованным. В частности, Н. А. Константинов и В. Я. Струминский с сожалением указывали на то, что замечательная и поучительная деятельность Н. Н. Блинова была впоследствии замолчана, а его работы преданы забвению (Konstantinov \& Struminskij, 1953, s. 180).

Причиной отмеченного этими авторами сложившегося положения в отношении научного наследия Н. Н. Блинова послужило то трагическое обстоятельство, что он неоднократно подвергался репрессиям со стороны властей. Священник Блинов за активное участие в издании «Вятской незабудки» и «Наглядной азбуки» подвергался обыску, ссылался в дальний приход под надзор полиции, лишался права работать в школе.

Продолжавшаяся в течение многих десятилетий пелена забвения вокруг имени этого просветителя значительно сузила возможности для изучения и использования их теоретико-методического наследства.

Николай Николаевич Блинов родился 7 (19) октября 1839 г. в селе Зашижемье Орловского уезда Вятской губернии в семье священнослужителя. В 1861 г. он окончил курс Вятской духовной семинарии и стал священником в удмуртском селе Карсовай Глазовского уезда, где по его настоянию открылась школа. В дальнейшем он совмещал церковную, педагогическую, этнографическую и писательскую деятельность.

В 1868 г. Вятское губернское земство выпускает руководство для учителей, составленное Блиновым под названием «О способах обучения предметам учебного курса начальных народных училищ» и книгу «Грамота. Учебник для народных школ». «Грамота» была рекомендована учебным комитетом Министерства народного просвещения и быстро распространилась в земских школах.

Затем он был учителем в вятском уездном городе Нолинске, где написал книгу «Ученье - свет». Интересный текст и иллюстрации (80 рисунков художника сарапульца В. И. Порфирьева) сделали книгу Блинова явлением в учебной литературе. В дополнение к ней он 
издал сборник стихотворений, пословиц и поговорок «Пчелка».

В 1872 г. Н. Н. Блинов участвовал в первом всероссийском съезде народных учителей в Москве, куда он был отправлен земством. Установив там прочные связи с известными педагогами и литераторами, он стал сотрудником ряда газет и журналов.

Велики были заслуги Н.Н. Блинова в области педагогической деятельности среди русских детей. Ему приходилось в печати и в практической учительской деятельности преодолевать косность старого духовенства. Так, ретрограды не мыслили обучение грамоте без обязательного повторения «глаголь - добро - есть...», считая эти слова чуть ли не за некие религиозные символы, без которых обучение грамоте никак не может обойтись. Свои дидактические взгляды педагог стремился воплотить в «бахтинский» период своей педагогической деятельности.

Важным этапом в жизни священника и учителя $\mathrm{H}$. Н. Блинова стал период его работы в крупном селе Бахта, расположенном в десяти верстах от Вятки. Вятский учитель-просветитель Дмитрий Илларионович Сенников в статье «Две школы» (имелись в виду организованные Н. Н. Блиновым школа для мальчиков и школа для девочек), опубликованной в «Вятских губернских ведомостях» (далее - «ВГВ») (1870, № 41) поражался небывалой для того времени постановкой школьного дела.

В школе (Блинов предпочитал говорить - «в школах», имея в виду классы для мальчиков и девочек) обучались в среднем 30 мальчиков и 20 девочек. Было введено наглядное обучение. Уроки сопровождались показом репродукций, иллюстраций, работой с картами. Вместе с Блиновым дети обрабатывали школьный садовый участок, сажали деревья, цветы, овощи, попутно знакомясь с основами ботаники и агрономии. В школе был введен ручной труд: мальчики обучались сапожному делу, девочки - шитью и вязанию.

Все это было делом новаторским для того времени, не говоря уж об уроках физкультуры, которые были обязательны в школе Н. Н. Блинова как для мальчиков, так и для девочек. Необходимость этих нововведений просветитель объяснял тем, что крестьянским женщинам нередко приходится выполнять тяжелую мужскую работу и поэтому девочки с ранних лет должны быть физически подготовленными.

Все указанные новшества проводились за счет личных средств учителя (кстати, отца одиннадцати детей). Жалованье уходило на приобретение физкультурных снарядов, книг и наглядных пособий, материалов для обучения детей ремеслу. Земство отпускало на школу крайне скудные средства.

Бахтинский период просветительской деятельности Н. Н. Блинова раскрывал протоиерей И. Ф. Фармаковский в своих воспоминаниях. Он рассказывал, как Блинов убеждал в Бахте крестьян, чтобы они отдавали в школу девочек. Крестьяне возражали: «Ну, на что девкам нашим грамота? Ведь не писарями же им быть?!» Но Блинов все-таки добивался своего. В женской школе с девочками занималась и его жена. Она обучала детей чтению, письму и арифметике, а заодно шитью, вязанию, вышиванию.

Практическую педагогическую работу отец Николай сочетал с научно-педагогической. Стремясь к наибольшей эффективности обучения, он обобщил свой, к тому времени уже богатый педагогический опыт, и опубликовал методические пособия для учителей: «Грамота: Учебник для народных школ» (Вятка, 1868, $1870,1872)$, «О способах обучения предметам учебного курса начальных народных училищ» (Вятка, 1870; СПб, 1875, 3-е изд.). В «ВГВ» публиковались его статьи, носившие по тем временам новаторский, остро полемический характер. Так, в статье «О мерах по улучшению преподавания в народных школах» (1869, №№ 11, 13) он выступил с широким просветительским планом усовершенствования педагогической работы. В частности, им предлагалось создание специальных педагогических библиотечек, проведение съездов и совещаний учителей. Его собственная библиотека впоследствии стала предметом специального изучения.

При этом Н. Н. Блинов, как и положено благонамеренному пастырю, добросовестно исполнял священнические обязанности в местной церкви, которая под его руководством была капитально отремонтирована. Была устроена ограда, и вся прихрамовая территория получила уютный и законченный вид.

Первые сведения о Н. Н. Блинове как об исследователе местного края датируются 1861 годом, когда в «ВГВ» вышли его статьи, носившие этнографический характер. В материале «Новое поветрие» (1861, № 29) он рассказывал о суеверном предубеждении крестьян-удмуртов против одежды из фабричных материалов.

В «Заметках о пермяках Вятской губернии» (1861, № 44, 45) едва ли не впервые в местной историографии он дал подробное описание быта этой народности, а в статье «О приемных покоях для больных» (1862, № 3) рассказал об отношении удмуртских крестьян к «казенной» медицине и способах народного целительства.

В последующие годы он увлеченно занимался изучением жизни местного населения, чему свидетельством являются его статьи в «ВГВ»: «Описание Карсовайского прихода Глазовского уезда» (1864, № 46, 48, 49), «Сельскохозяйственный быт пермяков и вотяков Карсовайского прихода» (1865, № 31, 33-37), «Инородцы северо-восточной части Глазовского уезда» (1865, № 59-67), «Влияние времени года на рождение и смертность» (1866, № 84-87), «Движение народонаселения в приходе села Карсовайского» (1869, № 14-22, 28-37).

Все указанные статьи не были просто заметками, а именно большими глубокими статьями, печатавшимися на протяжении ряда выпусков газеты.

Свою историко-этнографическую ценность эти и другие работы Блинова не только не утратили, но с течением времени приобретают все большую ценность, поскольку они являются одним из немногих источни- 
ков, а в ряде случаев единственным, в области исследования истории и культуры «малых народов».

В 1866 году «ВГВ» опубликовали знаменитый письменный памятник $\cdot \mathrm{V}-\mathrm{V}$ вв. «Повесть о стране Вятской» (другое название - «Повесть о городе Вятке»), вызвавший оживленную, и до настоящего времени незавершенную, дискуссию историков по вопросу о времени заселения русскими Вятской Земли. Это был так называемый «баженовский список». Блинов, ознакомившись с ним, сделал вывод о его неполноте и выдвинул свой, «блиновский» список. Дополнение, приведенное Н. Н. Блиновым, было опубликовано в «ВГВ» $(1866$, № 34, 45, 66).

В эти годы Блинов направляет свои работы в Вятский губернский статистический комитет, где они получают положительный отзыв и рекомендации к опубликованию. Исследование о Карсовайском приходе высоко оценивается Русским Императорским географическим обществом, и в итоге в 1866 г. автор работы - сельский священник и учитель принимается в действительные члены общества и награждается бронзовой медалью.

Но деятельность Н. Н. Блинова на педагогическом и публицистическом поприще вызвала недоброжелательное отношение местных властей. В 1875 г. он был «выведен за штат» и по требованию губернатора даже покинул Вятскую губернию. Блинов поехал в Санкт-Петербург, где поступил вольнослушателем на юридический факультет Петербургского университета.

В 1879 г. Н. Н. Блинов вернулся в Вятскую губернию и занял место священника в Сарапульском Вознесенском соборе, где прослужил много лет. Он возобновил свои краеведческие исследования, одновременно занимаясь литературной работой и участвуя в культурной жизни города.

В течение многих лет он был членом попечительного комитета публичной библиотеки Сарапульского земства. Принимал самое деятельное участие в организации и работе Сарапульского земского музея и общества изучения Прикамского края.

В 1880 г. он издал книгу «К 100-летнему юбилею г. Сарапула». Продолжая изучать архивные материалы, опубликовал «Историко-статистическое описание города Сарапула, Воткинского и Ижевского заводов» (1887). Им был написан драматический этюд «Свет и во тьме светит!», посвященный Л. Н. Толстому и являющимся своеобразным откликом на его пьесу «Власть тьмы».

В 1895 г. Н. Н. Блинов был переведен из Сарапула в удмуртское село Бемыж (Бемышево). Его интересовали бытовавшие в удмуртской среде обычаи и религиозные пережитки. Эти наблюдения легли в основу его книги «Языческий культ вотяков», экземпляр которой был подарен им В. Г. Короленко, выступавшему на Мултанском процессе в защиту удмуртов.

Закончив свое пастырское служение, семидесятилетний Н. Н. Блинов вернулся в Сарапул и вновь занялся краеведческой работой. Он выпустил книгу очерков
«Сарапул и Среднее Прикамье. Былое и современное» (1908), «Памятные книжки города Сарапула» на 19111912 гг, а также издал книгу о славной землячке Н. А. Дуровой «Кавалерист - девица Дурова - Чернова Александров».

В «Известиях Сарапульского земского музея» Н. Н. Блинов помещает ряд статей и заметок: «Сарапульская старина» (1913), этнографический очерк «Лапти», исторический очерк «Заселение Закамья» (1914). Последняя его статья «Церковь на Старцевой горе в городе Сарапуле» была опубликована на страницах первого выпуска «Известий Общества изучения Прикамского края» незадолго до его смерти.

Блинов автор большого числа статей и более чем двадцати книг, изданных в Москве, Санкт-Петербурге, Вятке и Сарапуле, среди которых «Народное образование в Вятской губернии за последние десять лет. 1864-1874», «Жизнь Робинзона», представлявшее собой изложение для детей известного романа Д. Дефо и др. В 1914 г. Н. Н. Блинову было присвоено звание «Почетный гражданин города Сарапула». Умер 31 декабря 1917 г. (13 января 1918 г.) в городе Сарапуле Вятской губернии.

Поистине всероссийскую славу и признание в учительской среде Н. Н. Блинову принесла книга «Ученье - свет» (М., 1873; Вятка, 1884). В своих воспоминаниях Н. Ф. Бунаков, рассказывая о событиях первого всероссийского съезда народных учителей 1872 года, вспоминал в своей книге «Как я стал и как перестал быть «учителем учителей», что «в вятской группе находился энтузиаст земской школы, педагог-священник Н. Н. Блинов, симпатичнейший человек, страстно преданный делу народного образования, широко понимавший задачу народной школы. Он тогда уже был известен своею умною книжкой «О способах преподавания предметов элементарного курса», написанной горячо и с хорошим пониманием дела, а теперь привез в Москву в рукописи свой новый труд «Ученье - свет», с которым познакомил меня и с которым я познакомил аудиторию, как с превосходным курсом «родиноведения» для народной школы. Книжка эта была издана в Москве Мамонтовым и до сих пор пользуется вполне заслуженным успехом» (Bunakov, 1953, s. 337).

Исключительно высоко оценивал методические изыскания вятского педагога Н. Ф. Бунаков в книге «Моя жизнь, в связи с общерусской жизнью, преимущественно провинциальной. 1837-1905», где он продолжил свои воспоминания о встречах с вятским педагогом на вышеупомянутом съезде: «Блинов Н. Н. познакомился со мной, показал и объяснил мне привезенные рукописи, которые привели меня в восторг. Работы были действительно оригинальные и достойные внимания, особенно «Ученье - свет», книга для чтения в совершенно новом роде, не шаблонный сборник бессвязных статей, а ряд оригинальных описаний и рассказов, начиная с крестьянской избы, выводящих читателя постепенно за околицу, в поле, в лес и на широкий простор Божьего мира» (Bunakov, 1909, s. 97). 
Столь высокая оценка работ и деятельности Блинова полностью совпадает с характеристиками, которые давали его методическим работам другие видные исследователи.

Н. В. Чехов отмечал, в частности, что до Н. А. Корфа «педагогические вопросы, связанные с постановкой школьного дела и методы преподавания разрабатывались у нас по преимуществу теоретически, без применения к действительным условиям русской национальной школы. Среди всех педагогов и методистов того времени исключение в этом отношении составлял земец Вятской губернии священник Блинов, видный педагог и самоотверженный деятель в области народного образования» (С̆ehov, 1912, s. 57).

Н. В. Чехов считал его методические работы одними из лучших из тех, что были созданы в тот период. Так что литературный и методический талант Блинова не вмещался в узкие рамки священнических, а также учительских обязанностей, которые ему приходилось выполнять. Поэтому неудивительно, что, по определению вятского историка В. А. Бердинских, Блинов был своеобразной «белой вороной», и даже изгоем в среде сельского приходского духовенства (Berdinskih, 1997, s. 133). Одновременно он пользовался большим почетом и уважением среди учительства Вятской губернии.

Ценность научно-методического наследия Блинова определяется двумя обстоятельствами. Первое обстоятельство состоит в том, что он, будучи последовательным сторонником Ушинского в области начального обучения, в своей активной педагогической деятельности, продолжавшейся более полувека, активно проводил в жизнь такие новаторские идеи великого русского педагога и его ближайших последователей, как народность, гуманность, природосообразность в обучении и воспитании.

Вслед за К. Д. Ушинским он неоднократно подчеркивал необходимость возможно более глубокого изучения природы ученика. Выступал за скорейшее введение всеобщего начального образования и как земский деятель и видный публицист (публиковался в «Неделе», «Биржевых ведомостях», «Русском обозрении», «Детском чтении», «Северном вестнике», «Мире Божьем», «Сельской беседе») всемерно способствовал этому.

Второе обстоятельство заключается в том, что, помимо просветительской работы в области распространения взглядов корифеев отечественной педагогики, вятский педагог стремился к формулированию в своих работах самостоятельных педагогических идей, нашедших свое воплощение, прежде всего, в таких его работах, как «Ученье - свет. Книга для чтения в народных училищах» (М., 1873; Вятка, 1884), «Замечания для учителей о классных занятиях по книге «Ученье - свет» Н. Блинова» (М., 1873) и «О способах обучения предметам учебного курса» (СПб., 1875. 3-е изд.).

Анализ пособий Н. Н. Блинова позволяет сделать вывод о том, что наиболее примечательной его чертой как методиста, был расчет «не на поспешность и усиленность занятий, а на применение к делу обучения разумных, упрощенных методов и на достаточность учебных пособий, соответствующих цели» (Blinov, 1875, s. 11).

Тем самым, педагог подчеркивал свою приверженность научно-обоснованным, продуманным методикам, прежде всего при обучении чтению, которое он считал основой основ в начальной школе. Поэтому он обращал особое внимание на «начальные приемы», справедливо полагая, что «хорошо начатое дело и продолжать нетрудно».

Он неоднократно отмечал у стремившихся работать творчески учителей «осознание необходимости введения улучшений», но одновременно указывал, что их многочисленные попытки в этом направлении нередко «не говорят в пользу самого дела». Разуверившись в предлагаемых методиках, учителя бросают их, находя «чересчур замысловатыми».

Н. Н. Блинова не удовлетворяли сформировавшиеся в учительской среде методические стереотипы, в частности стремление некоторых учителей начинать работу с детьми с «затверживания» всего алфавита. Он справедливо указывал, что «ни на одном языке нет таких слов, в которые входил бы не только весь алфавит, но хотя бы половина его; не всякая даже печатная страница совмещает в себе все буквы... К чему же тогда такая торопливость при изучении основ?» (Blinov, 1875, s. 12).

С целью преодоления вышеуказанных стереотипов Н. Н. Блинов разработал своеобразную методику обучения чтению. В ее основание он положил идею формирования, как он пишет, возможно более ясного понятия о звуке (букве), его изолировании или резком выделении среди других звуков (букв). Он предлагал в самом начале работы выделить два - три гласных звука, например, «а» и «о». Затем учитель дает описание случаев, когда человек вскрикивает: «Ай! Ой!» Потом эти звуки называются в словах: «мать», «кол», «сад», «дать», «дом», «шаг».

Следующий этап работы - определение этих звуков в начале, середине и конце слов: «ах», «ха», «шар», «сор». В дальнейшем даются слова, содержащие эти гласные вместе: «оба», «закон». За двусложными следуют многосложные слова, такие как «Маша», «Параша», и смешанные - «солома», «собака».

Аналогичным образом вятский методист предлагал изучать и другие гласные звуки и буквы. Согласные, по его методике, также должны были изучаться постепенно, «по одной зараз». При выборе порядка их изучения методист исходил из двух критериев: наибольшая протяженность звука («л», «с») и более «легкое» объяснение («м» - «мама»).

Таким образом, ко времени ознакомления с двумя-тремя согласными буквами ученики уже овладевали всеми гласными и поэтому могли читать легкие тексты, составлять довольно много слов и фраз и записывать их в тетрадь. «Вот основание метода обучения 
чтению, который только и может называться разумным», - несколько самоуверенно заявлял Блинов.

Ф. Ф. Павленков положил методические воззрения Блинова в основание своей «Наглядной азбуки», представлявшей собой такое учебное пособие, которое могло, по мысли автора, использоваться и без помощи учителя.

Однако Н. Ф. Бунаков, называя работу Павленкова оригинальной, талантливой и полезной, не разделял оптимизма Н. Н. Блинова по поводу того, что «эта азбука сделает возможным самообучение грамоте и быстро подвинет распространение грамоты в русском народе», хотя, «непобедимая вера в громадную силу грамоты и неукротимое стремление дать русскому народу эту силу внушали ему (Блинову. - В. П.) уверенность, что возможно осуществление такой утопии, как самообучение грамоте» (Bunakov, 1909, s. 98).

Вятский историк педагогики В. А. Петров, кстати, один из первых пятнадцати выпускников Вятского учительского института (1917 г.), давал положительную характеристику методике Н. Н. Блинова, подчеркивал ее логичность и доступность для рядового учителя (Petrov, 1954, s. 200).

Нам представляется в методике Н. Н. Блинова оригинальным и ценным наличие такого для того времени нового элемента в обучении грамоте, как четко установленная и наполненная конкретным содержанием поэтапность, известная в настоящее время под названием «алгоритмизация». В то же время, отдавая должное работе вятского методиста в области создания активной творческой методики обучения чтению, технология которой описана в его трудах и проверена на практике, заметим, что предлагавшаяся им методика не лишена существенных недостатков. Наиболее серьезным из них является то обстоятельство, что стремление к установлению строгой поэтапности в усвоении букв неизбежно должно было сопровождаться необходимостью введения слов, смысл которых был детям неизвестен.

Примечательно, что раскрывая очень подробно, с многочисленными примерами и ссылками на другие источники, разнообразные нюансы методики обучения чтению и письму, священник Блинов «укладывает» всю «методику» обучения церковно-славянскому языку в полстраницы.

Важнейшим средством обучения в начальной школе является книга. Сам Н. Н. Блинов лучшим из методических руководств считал пособия К. Д. Ушинского. Однако вятский педагог отмечал, что, пользуясь ими, учитель должен уметь методически обрабатывать содержащийся в них учебный материал, применяясь к требованиям сельского училища и возможностям его учеников. Отмечая, как положительную черту, энциклопедичность и содержательную насыщенность «Детского мира» и «Родного слова» К. Д. Ушинского, Блинов в то же время считал, что эти пособия больше подходят для городских, более развитых и подготовленных к школьному обучению детей. Рассказы в них, указывал вятский методист, идут «разъединенно», и хотя они связаны определенной логикой и последовательностью, сельскому ребенку, никогда не покидавшему своей деревни, чересчур сложно осознать некоторые сюжеты и понятия, которые относятся к тем сферам жизни, что выходят за пределы ежедневного бытия крестьянина.

Мы считаем подход Н. Н. Блинова к рассмотрению пособий Ушинского весьма упрощенным, а его аргументы по поводу якобы большей развитости городских детей по сравнению с сельскими - не вполне неубедительными.

Нам представляется недостаточно обоснованной и его критика в адрес работ великого русского педагога, ставших со времени своего появления на долгие годы основными пособиями для детского чтения и положивших начало изданию нового типа литературы - детской энциклопедии (детской хрестоматии); ни одна книга не может содержать такой объем материала и идей, которые бы отвечали всем потенциальным требованиям и запросам читателя; любая книга, как правило, решает локальную задачу.

Такую же частную задачу ставил перед собой и сам Н. Н. Блинов при составлении «первой книги для сельских ребят» под названием «Ученье - свет». В ней он предлагал вести ребенка «от семьи к деревне, от деревни к селу, затем к школе, в которой ему дается представление о широком Божьем мире».

Главное внимание в пособии уделяется обильно иллюстрированному связному повествованию, которое ведется от лица мальчика, постепенно открывающего для себя окружающий мир. Повествование разделено на отдельные рассказы - «случаи», логически связанные между собой.

Н. Ф. Бунаков высоко оценивал сочность, народность и, в то же время, исключительно ярко выраженную литературность языка, которым написана книга. Принцип наглядности в ней реализуется не столько посредством иллюстраций, как у Я. А. Коменского в «Мире чувственных вещей в картинках», не через точное и научное описание рассматриваемых объектов, как в вышеотмеченных работах К. Д. Ушинского, а преимущественно путем использования выразительных средств народного русского языка.

При этом Н. Н. Блинов не претендовал на энциклопедическую широту охвата проблем, присущую произведениям названных великих педагогов; такая задача им просто не ставилась, поскольку книга была предназначена лишь для первого года обучения.

Современный исследователь А. В. Блюм подчеркивал и другие достоинства книги Блинова, отмечал, что для нее «характерен глубокий гуманизм, она начисто лишена назидательно-нравоучительного тона, которым были проникнуты почти все издания подобного рода в то время» (Blûm, 1976, s. 37).

Н. Н. Блинов внес определенный вклад в решение проблемы использования основных дидактических принципов применительно к условиям начальной народной школы. 
Свои воззрения по этому вопросу он изложил в работах «Замечания для учителей о классных занятиях по книге «Ученье - свет» Н. Блинова» (М., 1873) и «О способах обучения предметам учебного курса» (СПб., 1875), ставших одними из первых российских методических пособий региональных авторов для начальной школы.

В них Н. Н. Блинов достаточно аргументировано обосновал необходимость использования основных принципов дидактики, в частности принципа сознательности в обучении. Так, будучи убежден, что ребенок только тогда относится к известному случаю, поступку и т. п. с должным вниманием, сознательно, когда ему известно хотя бы одно лицо, которое участвует в данном действии, методист берет в качестве этого лица самого мальчика - героя книги «Ученье свет», и предлагает учителю всегда ставить каждого ученика в то положение, в каком находится главное действующее лицо.

Он рекомендовал педагогам побуждать детей к составлению своих собственных «книг», то есть личных дневников, в которые они должны были записывать ежедневные впечатления и наблюдения. Немаловажное значение Н. Н. Блинов придавал реализации принципов доступности и последовательности в обучении, что находило отражение в его книге «Ученье - свет» в особом расположении материала, где деревенские реалии постепенно сменялись более сложными для сельских учащихся городскими сюжетами, а затем дети знакомились с жизнью других стран и народов.

Принцип посильности также нашел свое отражение в рассматриваемой книге Н. Н. Блинова. Она хоть и представляла собой единый рассказ, описание жизненных впечатлений одного мальчика, но одновременно подразделялась на отдельные главы. Ее автор справедливо полагал, что к чтению большого рассказа или к однообразному, «связному до педантизма» изложению дети на первых порах еще не готовы. Видимая же связь между всеми «рассказцами», создававшая иллюзию единого большого повествования, позволяла преодолевать детям страх перед чтением «толстых» книг.

Активная методическая деятельность Н. Н. Блинова в определенной степени способствовала утверждению среди учителей Вятской губернии принципа наглядного обучения. В своих выступлениях на съездах народных учителей и в методических пособиях он справедливо отмечал, что в начальные училища поступают дети разных возрастов, не одинаково развитые и обладающие различным, хотя, в целом, и не обширным запасом сведений и жизненных впечатлений. Однако каждый из этих детей обладает драгоценным качеством детства - живой восприимчивостью. С любопытством рассматривает ученик - новичок всякий предмет, хотя бы отчасти и известный ему, если ему указывают на новые, незамеченные им ранее особенности этого предмета. Это стремление к восприимчивости, «охоту к рассматриванию» и должен использовать учитель в первый год обучения. Ему следует обратить внимание детей на окружающие предметы, определить вместе с детьми внешние отличия и обучить их словесному описанию.

Особую роль в первый год обучения Блинов отводил возможно более широкому применению принципа наглядности, придавая ему даже самодовлеющее значение. Он полагал, что в первые месяцы обучения детей «не нужна будет никакая книга» (Blinov, 1873, s. 2). С таким подходом трудно согласиться, особенно если учесть, что во многих сельских школах обучение продолжалось «одну зиму», то есть всего четыре - пять месяцев.

Н. Н. Блинов указывал также на то, что, на его взгляд, полноценной первой книги для чтения пока не создано. Казалось бы, такое мнение представляется абсурдным для человека, который был даже лично знаком или состоял в переписке с некоторыми авторами учебных книг, получивших широкое признание, например с Н. Ф. Бунаковым. Однако он пояснял, что в настоящее время книги замечательных русских педагогов существуют, несмотря на все свои достоинства, как бы сами по себе, а нужно, чтобы они дополнялись и были тесно увязаны в содержательном отношении с «коллекцией наглядных пособий», которой пока нет.

Таким образом, вятским педагогом высказывалась оригинальная мысль о необходимости создания комплекса учебно-наглядных пособий, как для обучения грамоте, так и для последующих ступеней обучения. Реализация этой идеи осуществлялась самим Н. Н. Блиновым как в процессе его активной работы по созданию в городе Вятке первого педагогического кабинета, губернской земской мастерской учебно-наглядных пособий, так и при составлении им различных методических пособий.

Собственное понимание реализации принципа наглядности в обучении Н. Н. Блинов подробно рассматривает в книге «О способах обучения предметам учебного курса». Отмечая явную недостаточность учета этого дидактического принципа в практике работы российской начальной школы, он предлагал проведение самостоятельных уроков наглядного обучения, по четыре - пять уроков в неделю.

Разумеется, он не был первым, кто выдвигал и реализовывал в практической деятельности идею проведения наглядных уроков. Однако в то время она представлялась в провинции достаточно новой и оригинальной, поскольку сам принцип наглядности не считался общепризнанным среди сельского учительства, особенно среди законоучителей.

В содержание наглядных уроков Н. Н. Блинов включал беседы о свете, цвете, форме и величине тел, упражнения над различением звуков, ознакомление детей с физическими свойствами тел и их поверхностей и многое другое. Дальнейшее развитие уроков наглядного обучения Н. Н. Блинов связывал с введением элементов природоведения и родиноведения, в связи с реализацией принципа природосообразности.

Здесь в качестве отправной точки педагоги разных стран, как известно, избирали различные объекты. 
Так, Й. Г. Песталоцци предлагал начинать изучение ребенком окружающего мира с человеческого тела, немецкие педагоги - с вещей из домашней обстановки, педагоги Англии - с «естественных произведений и технических производств».

Н. Н. Блинов придерживался последнего мнения и считал, что только в этом случае в школу будет внесен тот элемент жизненности, который освободит ее от схоластики в процессе первоначального обучения и сделает последнее более наглядным (Blinov, 1875, s. 9).

Изучение природоведения и родиноведения, по мнению Н. Н. Блинова, может реализовываться не только в процессе книжного обучения в классе, но также и во внеурочное время. С этой целью учитель может воспользоваться прогулками с учениками в ближайший лес, в поле, на луга. В ходе экскурсий и сам учитель узнает много нового, а «полученные им сведения могут принести неоценимую пользу для... составителей руководств отчизноведения» (Blinov, 1875, s. 63).

Поэтому он советовал учителям во время экскурсий обращать внимание на географическое положение населенных пунктов, на горы, воды, почвы, животный и растительный мир, на характерные особенности местных жителей (внешность, национальность, одежда, пища, нравы, обычаи, песни, сказки, предания, поверья, занятия, промыслы, торговля и т. д.) и на собирание коллекций насекомых, растений, почв, минералов и т. д. С этой целью он считал необходимым учителю составлять «коллекции естественных произведений из трех царств природы».

Н. Н. Блинов неоднократно подчеркивал необходимость для учителей иметь в своем распоряжении доступные средства наглядности: картины, муляжи, модели и т. п. В этой связи заслуживает внимания его мысль о том, что практически любой предмет можно сделать учебным пособием. Так, «валяющийся у крыльца камень не вызывает в ученике никакого интереса, но принесите этот камень в класс и сделайте о нем беседу и увидите результаты. Дети видели в лесу тысячи сосновых и еловых шишек, но спросите, рассматривали ли они их внимательно, замечали ли они в них семена, зародыши будущих сосен и елей?» (Blinov, 1875, s. 9).

Таким образом, вятский методист возлагал немалые надежды на региональную составляющую («местный элемент» по Блинову) в содержании образования. Не случайно, отмечал он, «результаты получаются далеко лучшими, когда материалом обучения будет еще более близкое и родственное детям, а именно то, что может еще легче действовать на способность восприятия их» (Blinov, 1875, s. 9). Наглядные природные, предметные и словесные впечатления локального характера обогащают мышление учащихся настолько, что, как считал педагог, на последующем этапе развития их духовных сил дети не имеют недостатка в материале для упражнения своих мыслительных способностей.

Н. Н. Блинов призывал учителей овладевать богатым методическим арсеналом российской педагоги- ческой мысли. Так, им настоятельно рекомендовалась разработанная Ушинским методика рассказов по картинкам. Упражнения в пересказе содержания картинок, справедливо считал педагог, должны сочетаться с письменными упражнениями, под которыми он понимал «осмысленное употребление букв, слов, выражений и расположение слов» (Blinov, 1873, s. 58).

Вятский педагог поддерживал плодотворную идею русского педагога В. И. Водовозова об «обстоятельном словесном и вещественном разборе статей, дающем достаточный материал для письменных работ учеников» (Blinov, 1873, s. 56).

В опоре на достижения передовой российской методической мысли, нашедшей свое наиболее яркое проявление в трудах К. Д. Ушинского и его единомышленников и последователей, Н. Н. Блинов стремился в своих пособиях выразить собственное понимание целесообразной организации процесса обучения. Например, он предлагал разнообразить уроки чтения в зависимости от степени подготовленности учащихся и характера изучаемого материала, и либо сразу приступать к чтению избранного учителем отрывка текста, - в случае, если он своим содержанием вызывает в сознании детей хорошо им известные и «понятные до отчетливости обстоятельства», либо сначала провести предварительную беседу, в ходе которой внимание детей должно быть обращено на предметы и обстоятельства, о которых позднее пойдет речь в избранном для чтения отрывке текста.

Такие беседы, указывал Блинов, чаще должны иметь место в начальный период обучения. Так, при работе над рассказом «Деревня» из книги «Ученье свет» методист советовал учителю начинать урок с обращения к детям рассказать о своей деревне. После этого чтение должно пойти легче, так как оно будет опираться на знакомый детям материал и только что употребленные в речи слова.

В качестве следующего этапа работы над данной темой Блинов советовал предложить детям составить, опираясь на лексическое содержание начального этапа урока, словесное описание своих деревень (каждому ученику - своей), и потом совместно - рассказ о селе, в котором находится школа.

Этот последний рассказ в коротких, простых предложениях записывается учителем на классной доске. Как вариант он рекомендовал самостоятельную запись детьми составленного ими рассказа.

Письменные упражнения, под которыми Блинов понимал «осмысленное употребление букв, слов, выражений и расположение слов», должны были идти одновременно с чтением книги, ибо только через практику дети могут привыкнуть к грамотному выражению своих мыслей, чему, по мнению Н. Н. Блинова, способствует «обстоятельный словесный и вещественный разбор статей, дающий достаточный материал для письменных работ учеников» (Blinov, 1873, s. 58).

Следует признать, что вышеприведенные методические советы и рассуждения вятского педагога не 
были вполне оригинальными. Здесь Блинов по своему интерпретировал руководства и объяснительные записки К. Д. Ушинского к книгам «Детский мир» и «Родное слово» (Ušinskij, 1989c, s. 6-7; Ušinskij, 1989b, s. 8-20; Ušinskij, 1989a, s. 8-22; Ušinskij, 1989d, s. 24-88).

Ценность этих методических советов, приведенных в работах Блинова состояло, прежде всего, в том, что указанные работы великого русского педагога находились достаточно длительное время под запретом и поэтому учителя Вятской и соседних с ней губерний получали возможность ознакомиться с богатым методическим наследием российской педагогической мысли в популярном изложении вятского методиста.

Н. Н. Блинов не замыкался на использовании достижений российских педагогов. Из опыта немецких детских садов Блинов предлагал перенести в русскую начальную школу «дары Фрёбеля», черчение по клеткам, плетение, работу с бумагой, глиной и другими материалами, подвижные игры с мячом.

Последние он связывал с преподаванием пения, которое тогда носило исключительно религиозный характер. По его мнению, пение должно быть и светским, служить своего рода фоном для игр и важным средством передачи молодому поколению народной памяти.

Стремление вятского педагога к освоению передовых методических образцов, в том числе и зарубежных, подчас оборачивалось копированием не только позитивного, а и, на наш взгляд, несколько консервативного опыта. В качестве примера укажем на некоторое заимствование из книги одного из сотрудников выдающегося немецкого педагога Фридриха Фрёбеля Генриха Лавенталя «Первое школьное обучение. Пособие учителям начальной школы» (М., 1867).

Немецкий методист предлагал в течение нескольких месяцев задавать детям при ознакомлении с окружающими их в школе элементарными вещами вопросы типа: «Что это такое? Что есть у предмета? Для чего? Откуда? Зачем? Из чего сделан?» и т. п. Подобный методический педантизм, заимствованный Н. Н. Блиновым у Г. Лавенталя, а также у Н. Ф. Бунакова, проявился почти дословно в книге вятского педагога «О способах обучения предметам учебного курса». Постановка подобного рода вопросов расценивалась видными педагогами отнюдь не как реализация принципа постепенности в обучении и вызвала едкие, ироничные замечания со стороны, в частности, Л. Н. Толстого.

В то же время, демократизм взглядов Блинова, его сочувственное отношение к крестьянам наглядно проявились в отношении к его работам со стороны официального чиновничества. Пытаясь расширить сферу применения своих книг и получить средства на издание их дополнительного тиража, Блинов обратился с этой целью в особый отдел ученого комитета Министерства народного просвещения, но в итоге только навредил делу.

Цензор особого отдела Сент-Илер писал в своей рецензии: «Мальчик (герой книги «Ученье - свет». В. П.) задумывается над тем, отчего некоторые живут богато, а другие - бедно, и задает себе вопрос «Зачем не только в разных местах, но и в одной деревне у одних всего довольно, а другие перебиваются с куска на кусок?» Прямого ответа на этот важный вопрос нет в книге... Все статьи о неравенстве состояний кажутся нам неуместными. Сами вопросы эти не должны составлять материала для классных бесед. Нет никакой причины особенно возбуждать в детях вопросы о бедности и богатстве» (CGIA RF. F. 734, s. 490492). В итоге, было разрешено использование лишь «Пчелки», представлявшей собой сборник безобидных стихов, пословиц и сказок для детского чтения, а книги «Ученье - свет», «Замечания для учителей...», «О способах обучения...» подверглись запрету.

Научно-методическая и практическая педагогическая деятельность Блинова - яркое явление в истории российского провинциального образования. «Симпатичный образ этого русского народного учителя - энтузиаста, с одушевлением и какой-то нервной торопливостью излагающего свои чистые и честные идеи о народном просвещении, о народной школе, народном благе, никогда не изгладится в моем воображении», писал о нем Н. Ф. Бунаков (Bunakov, 1909, s. 241).

Важнейшей чертой практической педагогической деятельности и методического наследия Н. Н. Блинова выступает их актуальность и значительная ценность для дела начального просвещения крестьянского населения. Близость просветителя к народу, постоянная учительская работа в его среде, своевременный учет запросов и требований времени, литературный и педагогический талант позволили создать ему отвечавшие самым высоким методическим требованиям исторического периода произведения, применение которых в школах существенным образом повлияло на качество обучения.

Региональные особенности Вятского края и соседних с ним регионов наложили явственно ощущаемый отпечаток на содержание их трудов. В частности, полиэтнический состав населения обусловил необходимость разработки учебно-методических пособий для нерусских народов. Значительная часть педагогической деятельности Н. Н. Блинова была посвящена обучению удмуртских детей, для которых им была составлена первая удмуртская грамота «Лыдзон» («Чтение») (Вятка, 1867).

В ее основу была положена графика русского языка с добавлением надстрочных знаков для выражения специфических звуков удмуртской речи, а самое главное - новаторский для того времени звуковой метод обучения грамоте, предложенный К.Д. Ушинским. Следует заметить, что первая удмуртская азбука была написана иереем из удмуртского села Укан И. Анисимовым и издана в Казани в 1847 г. Но это было сугубо богословское издание, построенное на переложении краткого катехизиса. Поэтому первой полноценной с дидактической точки зрения азбукой-букварем следует считать труд Н. Н. Блинова.

В этой азбуке приведены в определенной системе слоги, слова и выражения, даны переводы молитв 
и впервые на удмуртском языке прозаические отрывки светского нравоучительного содержания. Здесь же помещен первый перевод поэзии А. С. Пушкина на удмуртский язык, осуществленный Блиновым. Свою рукопись Блинов направил в Вятский губернский статистический комитет, который в те годы был в Вятской губернии по существу центром культурной жизни. В своем обращении в комитет он писал: «За составление ее (азбуки - В. П.) назад тому более года я взялся вследствие настоятельной необходимости, так как поступавшие ко мне для обучения вотские мальчики, не понимая русского языка, с большим трудом знакомились с русской грамотой» (А.N., 1893, s. 3).

И помощь была оказана: Вятский губернский статистический комитет направил ее на рецензию известному вятскому издателю и журналисту Николаю Ивановичу Золотницкому, жившему в то время в слободе Кукарка Вятской губернии фактически в ссылке. Получив от него положительный отзыв, комитет стал хлопотать об издании работы. Комитет возбудил ходатайство перед губернатором, затем перед Московским цензурным комитетом и, в итоге, азбука была издана быстро, - в Вятке в 1867 г, а затем и в Москве. В дальнейшем она неоднократно переиздавалась и совершенствовалась другими авторами.

Издание этой азбуки поставило Н. Н. Блинова в один ряд с видными российскими просветителями «малых народов». Успех издания вдохновил автора на издание других работ. Его работа по составлению методической литературы для средневолжских народов была продолжена и значительно усовершенствована И. С. Михеевым.

Методические взгляды Н. Н. Блинова до настоящего времени остаются современными и не утратившими своего значения. Вятский просветитель внес вклад в развитие национальной культуры и литературы, выступив автором оригинальных литературных этнографических, драматических, исторических, биографических произведений.

Блинов не принадлежал к какой-то определенной научной группе. Он был единственным в своем роде ученым-методистом, учителем и священником. Подчас ему приходилось страдать именно потому, что нападавшие на него знали, что Блинов - один, его никто не поддержит и никто не защитит (Bogdanovič, 1898). В качестве примера приведем историю с изданием в 1873 г. Ф. Ф. Павленковым в Санкт-Петербурге своей азбуки. Книга вышла с фамилией Блинова на обложке, который был вынужден дать на это согласие в интересах дела просвещения, хотя и предвидел для себя возможные неприятности, которые, действительно, не замедлили сказаться: последовали обыск, отстранение от учительской работы.

Спустя 15 лет, когда ссылки и цензурные придирки в отношении данного издания были далеко в прошлом, и можно было «смело» указать на свое авторство, в предисловии к очередному изданию «Объяснения к «Наглядной азбуке» Ф. Ф. Павленков вдруг счел необходимым заявить следующее: «Составление «Наглядной азбуки» до последних лет приписывалось о. (отцу. - В. П.) Блинову, который долгое время ничего не имел против этого. Но после упреков, которые были им обращены ко мне по поводу будто бы невыгодных последствий от такого недоразумения, я считаю вполне позволительным для себя заявить теперь, что отцу Блинову не только не принадлежит ни одной строки в «Наглядной азбуке» и «Чтении-письме по картинкам», но что до окончания моей работы он даже не верил в возможность практического осуществления той мысли, которая была положена мной в основание этих азбук. В своей «Грамоте», рекомендованной министерством народного просвещения, о. Блинов держался совершенно иной системы и даже стоял за раздельное обучение чтению и письму» (Pavlenkovf, 1887, s. 4).

Совершенно необходимо отметить, что такое «признание», мягко говоря, не делало чести известному издателю. Получилось так, что когда издание книги было делом опасным, но, в то же время, сама необходимость издания была для Павленкова делом принципа, авторство им было великодушно отдано Блинову; спустя же годы, когда об изданной некогда вольнодумной книге можно было говорить без опасений, Павленков вдруг забеспокоился о своем авторстве. Но ведь Блинов-то в свое время от этого навязанного ему «авторства» пострадал, и очень сильно! Он принял эту опасную миссию на себя и лишился работы, будучи отцом одиннадцати детей! А теперь «гроза миновала», и «славу борца» пожинал другой «герой»!

Бурная, насыщенная жизнь Н. Н. Блинова заслуживает дальнейшего изучения, так же как и его многочисленные труды. Кстати, в настоящее время в России проживают многочисленные потомки видного российского священника и педагога-методиста.

\section{Библиография}

A. N. (1894). Recenziâ na knigu I. Sil'čenko «Rodnaâ azbuka» (Odessa, 1893). Russkaâ škola.(5-6), 290.

Berdinskih, V. A. (1997). Vâtskij sunduk: Zanimatel'noe kraevedenie.

Blinov, N. N. (1873) Zamečaniâ dlâ učitelej o klassnyh zanâtiâh po knige "Učen'e-svet» N. Blinova.
Blinov, N. N. (1875). O sposobah obučeniâ predmetam učebnogo kursa.

Blinov, N. N. (1991). Stradaniâ velikogo učitelâ, Gospodai Spasitelâ našego Iisusa Hrista (dlâ semejnogo čteniâ). Ural'skij sledopyt (3 8), 15-19.

Blûm, A. V. (1976). F. F. Pavlenkov v Vâtke. 
Bogdanovič, A. I. (1898). «Učenye» otkrytiâ N. N. Blinova v voprose o votâkah i ih kul'ture. Mir Božij (12), 12-22.

Bunakov, N. F. (1892). Blinov Nikolaj Nikolaevič.V kn.: Kritikobiografičeskij slovar' russkih pisatelej i učenyh / sost. S. A. Vengerov. t. 3, s. 381-389. Sankt-Peterburg.

Bunakov, N. F. (1953). Kak â stal i kak perestal byt'«učitelem učitelej». W: Izbr.ped. soč. s. 328-395.

Bunakov, N. F. (1909). Moâ žizn', v svâzi s obŝerusskoj žizn'û, preimusestvenno provincial'noj. 1837-1905.

Gorbunov, Û. A. (1981). Dan' svoemu vremeni. Ural, (2), 175-184.

Gorbunov, Û. A. (1991). Stradaniâ velikogo učitelâ. Ural'skij sledopyt, (7), 2-5.

Izergina, N. P. (1990). Literaturnaâ žizn' Vâtki (s. 206).

Konstantinov, N. A., Struminskij, V. Â. (1953). Očerkipo istorii načal'nogo obrazovaniâ $v$ Rossii.

Pavlenkovf, F. (1887). Ob"âsnenie k «Naglâdnojazbuke» (Klûč k čteniû $i$ pis'mu po kartinkam).

Petrov, V. A. (1954) Zemskaâ načal'naâ škola v Vâtskoj gubernii: dis. ... kand. ped. nauk.

Povarova, E. V. (1980). Naučno-pedagogičeskaâ deâtel'nost' prepodavatelej Peterburgskoj učitel'skoj seminarii. Sovetskâ̂ pedagogika, (6), 117-122.
Pomelov, V. B. (1998). Pervyj vâtskij avtor učebnikov I.F. Âkovkin. W: Petrâevskie Čteniâ- 98.

Prutkovskaâ, R. A. (1969). Stanovlenie i razvitieprogrammy i učebnika istorii srednej školy v Rossii (konec XVIII - do načala $60-h$ gg. XIX v.): dis. ... kand. ist. nauk.

Semenov, D. D. (1953). Opyt pedagogičeskoj kritiki russkojèlementarno-učebnoj literatury (1887-1888). W: Izbr. ped. soč.

Ušinskij, K. D. (1989a). O pervonačal'nom prepodavanii russkogoâzyka. W: Sobr. soč. 6 t. (t. 4, s. 8-22).

Ušinskij, K. D. (1989b). Predislovie (k knige «Detskij mir»). W: Sobr. soč. 6 t. (t.3, s.8-20).

Ušinskij, K. D. (1989c). Predstavlenie v sovetvospitatel'nogo obŝestva: Ob izdanii knigi dlâ čteniâ. W: Sobr. soč. 6 t. (t.3, s.6-7).

Ušinskij, K. D. (1989d). Rodnoe slovo. Kniga dlâ učaŝih. W: Собр. соч. 6 t., t. 4. s. 24-88.

Ušinskij, K. D. (1989e). Cvety moskovskoj pedagogii na peterburgskoj počve. W: Sobr. soč. 6 t. (t.3. s.474-496).

Čehov, N. V. (1912) Narodnoe obrazovanie v Rossii s 60-h gg. XIX v. (s. 224).

CGIA RF. F. 734. Op. 36. 1874. D. 26. L. 490-492.

Rozmiar artykułu: 1,5 arkusza wydawniczego 